\title{
COMPREHENSIVE EVALUATION OF LABOUR EFFICIENCY AT MACRO- AND MESOECONOMIC LEVELS IN UKRAINE
}

\author{
Olena Mahopets ${ }^{1}$, Tetiana Korneeva ${ }^{2}$ \\ ${ }^{1,2}$ Central Ukrainian National Technical University, Kropyvnytskyi, Ukraine \\ e-mails: ${ }^{1}$ oamahopets@ukr.net, ${ }^{2}$ korneevats16@gmail.com
}

Received: 01 July 2020; Accepted: 13 August 2020; Published: 01 January 2021

\begin{abstract}
The article is devoted to the evaluation of labour efficiency at macro-and mesoeconomic levels in order to form the principles of public administration. Special attention is paid to the development of a complex approach to assessing labour efficiency. It is based on the systematization of 36 indicators by main groups: the state of the use of fixed capital; investment activity; innovative activity; use of working time; composition of the payroll budget; formation and use of personnel. A comprehensive analysis and assessment of labour efficiency at macro-and mesoeconomic levels will make it possible to identify and play a significant role in growing reserves of labour efficiency factors. The results of the research have shown that at macro-, mesoeconomic levels there are significant reserves for labour productivity growth by increasing technical level of production, efficient investment and innovation activities, improving the use of working time with minimizing losses, changes in production, labour and management, material incentives and raising educational and qualification levels. It is proved that in the group of factors "Composition of the payroll budget" the decrease in incentive and compensation payments and additional wages in the payroll budget for led to a decline in labour productivity index at the level of national economy and labour productivity index at the level of Kirovohrad region. It is established that influential factors from the group "Formation and use of personnel" index of the coefficient of advanced training of the average number of full-time employees; index of the coefficient "Trained in new professions in relation to the average number of full-time employees"; index of the share of the employed population with a complete higher education.
\end{abstract}

Key words: labour, efficiency, productivity, factors, comprehensive, evaluation, capital, investment, personnel.

JEL classification: A10, E24, J08

\section{Citation:}

Magopets O., Korneeva T. 2021. Comprehensive evaluation of labour efficiency at macro- and mesoeconomic levels in Ukraine. Access to science, business, innovation in digital economy, ACCESS Press, 2(1): 50-77.

https://doi.org/10.46656/access.2021.2.1(5)

\section{INTRODUCTION}

Improvement of labour efficiency at the level of national economy of Ukraine is a major criterion of economic growth, steady rise in living standards, growth of social and labour activity. At the regional level, it is a necessary condition for increasing product competitiveness and efficiency of regional enterprises.

Increasing labour efficiency improves the balance among economic, social and political structures of a society and strengthens economic security of a country.

Thus, labour efficiency has a beneficial effect on all sectors of the economy. It is possible to get out of the crisis only on the basis of its improvement. 
The analysis of scientific research shows that a comprehensive system of indicators assessing labour efficiency at macro- and mesoeconomic levels has not yet been formed, and there is no systematization and parameterization of this set.

National and foreign economists and scientists Vorobyova, Odintsov (2015), Golovanov (2013), Pogorelova (2016), Potudanskaya (2013), Samoilenko (2011), Semykina (2010), Semiv (2013), Serhiychuk (2011), Suvorova (2011), Turchina (2013), Chernushkina (2013), Yarchuk (2014), Naama (2001), Vazov (2019), Lazarova, Zhelyazkova \& Vazov (2015), Petrova et al. (2020), Ocheredco (2020) and others made a significant contribution to the development of approaches, methods and models of labour efficiency evaluation.

Some practical issues related to determining the impact of a group of indicators (the state of use of fixed capital, investment and innovation, use of working time, composition of the payroll budget, formation and use of personnel) on a comprehensive assessment of labour efficiency at macro and mesoeconomic levels remain not yet fully considered.

\section{The purpose of the work}

The research task is to develop a comprehensive approach to assessing labour efficiency using already known and developed by us indicators (indices) in order to form the principles of public management of labour efficiency.

\section{Results}

Efficiency is a concept that finds use in theory and practice in a number of areas of human activity (Radukanov, 2014). Labour efficiency is a dynamic indicator that changes under the influence of a number of factors. It has been revealed that labour efficiency management should be considered through the system of complex and balanced factors of economic development, industry and the region (Baklanova, Petrova, Koval, 2020). Study of the impact on the dynamics of labour efficiency at macroeconomic and mesoeconomic levels is based on the author's methodological developments, which systematize 36 indicators by major groups: the state of use of fixed capital; investment activity; innovation activity; use of working time; composition of the payroll budget; formation and use of personnel (Semiv, 2013; Potudanskaya, Karkoshkina, 2013).

The results of a comprehensive and systematic study of labour efficiency (productivity) at the level of national economy and at the regional level are given in Tables 1 and Table 2 (Ukraine and separately Kirovohrad region during 2005-2018). Hereinafter, we will use the term "labour productivity" guided by the guidelines for calculating the resource intensity of gross domestic product by main groups of resources, labour productivity, rate of return on fixed assets at the level of national economy, regional level and economic activity (Ministry of Economic Development and Trade of Ukraine, 2019). 
According to Tables 1 and 2, labour productivity at the level of national economy of Ukraine for the period of 2005-2018 increased by $919.5 \%$. There is a gradual increase in Ukraine's GDP and reduction in the number of employed people in the economy by $26.4 \%$ - from 20.680 million people (2005) to 16.361 million people (2018). In 2014, compared to 2013, the number of employed people in the economy decreased by 11.4\% due to leaving abroad of the part of working population (State Statistics Service of Ukraine, 2020). This led to the loss of much of the country's labour potential, as well as due to hostilities in eastern Ukraine and temporary occupation of the Autonomous Republic of Crimea and part of the territories of Donetsk and Luhansk regions.

The study of labour productivity index at the level of national economy (IY) shows that the dynamics of change in this indicator is a wave. It decreased from 1.311 in 2008 to 1.001 in 2009 (by 23.6\%), and from 1.201 in 2011 to 1.041 in 2013 (by 13.3\%). In general, for the period of 2006-2018, labour productivity index decreased by $4.228 \%$.

Labour productivity in Kirovohrad region in 2005 amounted 15032.0 UAH / person, and in 2018 it was 169346.0 UAH / person (there was an increase of 154314.0 UAH / person). The index of labour productivity in Kirovohrad region (IY) increased by $1.348 \%$ during $2005-2018$. The same pattern is observed both at the national and regional levels: the number of employed population in Kirovohrad region decreased during the period of $2005-2018$ by $16.8 \%$ (from 457.5 to 380.5 thousand people), and the gross regional product of Kirovohrad region increased by $837.0 \%$ (from 6877.0 to 64436.0 million UAH in actual prices) (Main Department of Statistics in Kirovohrad region, 2020; State Statistics Service of Ukraine, 2020).

To make international comparisons of labour productivity among countries, "Gross Domestic Product" (GDP) at purchasing power parity in 2011 in the period (t) can be considered as the most reasonable. The calculation is made in millions of G-K dollars. Thus, labour productivity for international comparisons in 2005 equalled 15892.9 G-K dollars per person, and in 2018 - 32628.3 G-K dollars per person (there was an increase of 105.3\%). Labour productivity index for international comparisons for the period of 2006-2018, on the contrary, shows a downward trend of 5.344\% (Main Department of Statistics in Kirovohrad region, 2020).

Labour productivity in the industry of Ukraine in 2005 equalled UAH 29460.0 / person and had a tendency to increase. In 2018 it amounted to UAH 308729.0 / person (by 948.0\%). This is due to a decrease (by $40.4 \%$ ) in the number of employed people in the industry from 4072.4 thousand person (2005) to 2426.0 thousand person (2018). At the same time, gross value added in the industry (in actual prices) increased by $524.3 \%$, from 119971.0 million UAH (2005) to 748977.0 million UAH (2018). The index of labour productivity in the industry of national economy of Ukraine during 2006-2018, on the contrary, shows the dynamics of decrease by $5.626 \%$.

Labour productivity in the industry of Kirovohrad region during 2005-2018 increased by $939.5 \%$ due to a decrease in the employed population by $23.8 \%$ (from 64.6 to 49.2 thousand person) and an increase in gross value added in the industry by $691,7 \%$ (from 1360.0 to 10767.0 million UAH in actual prices). Labour 
productivity index in the industry of Kirovohrad region, on the contrary, decreased by $3.157 \%$ (from 1.267 in 2006 to 1.227 in 2018).

When studying the influence of the group of factors of "State of use of fixed capital" on labour productivity at the level of the national economy of Ukraine for 14 years (2005-2018), the following trends are observed (Fig. 1) regarding the factors:

$\mathrm{X}_{1}$ - is fixed assets in the economy from 2005 to 2018 that increased by 8333799.0 million UAH, or by 653.0\%. Maximum growth of fixed assets was recorded in 2014 and amounted to 13752117.0 million UAH, which in turn led to an increase in the indicator of capital-labour ratio $\mathrm{X}_{3}$ (in 2005-2018 by $852.0 \%$ ). Positive changes in the value of fixed assets were influenced by price leaps, adopted depreciation mechanisms and the results of state indexations. Their consequence was the accounting of the same means of production by model, productivity and year of purchase at a significantly different cost.

In 2018, the capital-labour ratio amounted to 587.4 thousand UAH per employee in the economy, and in 2014 this figure reached its maximum value and amounted to 760.9 thousand UAH. This is due to the fact that in 2014 there was a maximum increase in fixed assets and a reduction in the number of employed people in the country.

Fixed assets in the economy of Kirovohrad region for the period of 2005-2018 increased by $182.1 \%$ from 21611.6 to 60974.0 million UAH in actual prices (Fig. 2). There was also an increase in capital-labour ratio by $240.9 \%$ - from 47.2 to 160.9 thousand UAH per person employed in the economy.

The experience of developed countries shows that labour productivity increases with the growth of capital-labour ratio (Yankovyi et al., 2019). Technical re-equipment of production, introduction of the newest technologies, equipment, automation of manufacture, updating and replacement of the outdated equipment leads to an increase in cost of fixed assets and workplaces. Modern high-tech equipment provides more efficient use of labour force, replacing live labour with machine, which leads to increased productivity (Semykina, 2010).

The indicator of wear reflects qualitative characteristics of fixed assets, and the renewal indicator shows the dynamics of their reproduction. Effective formation and use of fixed assets is the growth of their value through the commissioning of fixed (new) production assets. Thus, the wear indicator from 2005 to 2018 increased by 11.6 percentage points (from $49.0 \%$ to $60.6 \%$ ). There is a gradual loss of fixed assets of consumer, physical, chemical properties, which leads to lagging behind modern technical, social and economic characteristics. The sharpest growth of this indicator occurred in 2014 (83.5\%). That is, on average for the period of 2005-2018 at the level of the national economy fixed assets were depreciated by $64.0 \%$. The coefficient of wear in the economy of Kirovohrad region for the period of 2005-2018 increased by 7.5 percentage points from $49.0 \%$ to $56.5 \%$.

$\mathrm{X}_{6}$ - is the coefficient of renewal of fixed assets which reflects the share of the cost of replaced old means of labour with new more productive, or at the expense of facilities that were in operation. 
Table 1. Indicators of labour productivity at the level of national economy of Ukraine, 2005-2018

\begin{tabular}{|c|c|c|c|c|c|c|c|c|c|c|c|c|c|c|c|c|c|}
\hline \multirow{2}{*}{ Indicator } & \multirow{2}{*}{$\begin{array}{l}\text { Unit of } \\
\text { Measure }\end{array}$} & \multicolumn{14}{|c|}{ Years } & \multicolumn{2}{|c|}{$\begin{array}{c}\text { Deviation, } \\
\text { 2018/2005* }\end{array}$} \\
\hline & & 2005 & 2006 & 2007 & 2008 & 2009 & 2010 & 2011 & 2012 & 2013 & 2014 & 2015 & 2016 & 2017 & 2018 & $\begin{array}{c}\text { absolute } \\
+/-\end{array}$ & relative\% \\
\hline 1 & 2 & 3 & 4 & 5 & 6 & 7 & 8 & 9 & 10 & 11 & 12 & 13 & 14 & 15 & 16 & 17 & 18 \\
\hline $\begin{array}{l}\text { Labour } \\
\text { productivity } \\
\text { at the level } \\
\text { of national } \\
\text { economy }\end{array}$ & $\begin{array}{l}\text { UAH/ } \\
\text { person }\end{array}$ & 21346,8 & 26249,5 & 34476,5 & 45205,8 & 45233,0 & 53259,0 & 63963,3 & 69011,9 & 71809,4 & 87805,8 & 120935,6 & 146548,3 & 184691,9 & 217627,0 & 196280,2 & 919,5 \\
\hline $\begin{array}{l}\text { Labour } \\
\text { productivity } \\
\text { index at the } \\
\text { level of } \\
\text { national } \\
\text { economy }\end{array}$ & & 1,000 & 1,230 & 1,313 & 1,311 & 1,001 & 1,177 & 1,201 & 1,079 & 1,041 & 1,223 & 1,377 & 1,212 & 1,260 & 1,178 & $-0,052$ & $-4,228$ \\
\hline $\begin{array}{l}\text { Labour } \\
\text { productivity } \\
\text { for } \\
\text { international } \\
\text { comparisons }\end{array}$ & $\begin{array}{l}\text { G-K } \\
\text { Dollar/ } \\
\text { person }\end{array}$ & 15892,9 & 17549,6 & 19227,2 & 19988,7 & 17831,8 & 18662,8 & 20036,7 & 20929,3 & 23836,7 & 25562,3 & 26484,8 & 29226,6 & 31217,5 & 32628,3 & 16735,4 & 105,3 \\
\hline $\begin{array}{l}\text { Labour } \\
\text { productivity } \\
\text { index for } \\
\text { international } \\
\text { comparisons }\end{array}$ & & 1,000 & 1,104 & 1,096 & 1,040 & 0,892 & 1,047 & 1,074 & 1,045 & 1,139 & 1,072 & 1,036 & 1,104 & 1,068 & 1,045 & $-0,059$ & $-5,344$ \\
\hline $\begin{array}{l}\text { Labour } \\
\text { productivity } \\
\text { in industry } \\
\text { of the } \\
\text { national } \\
\text { economy }\end{array}$ & $\begin{array}{l}\text { UAH/ } \\
\text { person }\end{array}$ & 29460,0 & 37180,0 & 49929,0 & 64026,0 & 60435,0 & 74828,0 & 89024,0 & 93725,0 & 92551,0 & 112222,0 & 152742,0 & 202594,0 & 259316,0 & 308729,0 & 279269,0 & 948,0 \\
\hline $\begin{array}{l}\text { Labour } \\
\text { productivity } \\
\text { index in } \\
\text { industry of } \\
\text { the national } \\
\text { economy }\end{array}$ & & 1,000 & 1,262 & 1,343 & 1,282 & 0,944 & 1,238 & 1,190 & 1,053 & 0,987 & 1,213 & 1,361 & 1,326 & 1,280 & 1,191 & $-0,071$ & $-5,626$ \\
\hline
\end{tabular}

Source: own study based on State Statistics Service of Ukraine (2020) 
Table 2. Indicators of labour productivity at the regional level - Kirovohrad region, 2005-2018

\begin{tabular}{|c|c|c|c|c|c|c|c|c|c|c|c|c|c|c|c|c|c|}
\hline \multirow{2}{*}{ Indicator } & \multirow{2}{*}{$\begin{array}{l}\text { Unit of } \\
\text { Measure }\end{array}$} & \multicolumn{14}{|c|}{ Years } & \multicolumn{2}{|c|}{$\begin{array}{l}\text { Deviation, } \\
\text { 2018/2005* }\end{array}$} \\
\hline & & 2005 & 2006 & 2007 & 2008 & 2009 & 2010 & 2011 & 2012 & 2013 & 2014 & 2015 & 2016 & 2017 & 2018 & $\begin{array}{c}\text { absolute } \\
+/-\end{array}$ & $\begin{array}{c}\text { relative } \\
\%\end{array}$ \\
\hline 1 & 2 & 3 & 4 & 5 & 6 & 7 & 8 & 9 & 10 & 11 & 12 & 13 & 14 & 15 & 16 & 17 & 18 \\
\hline $\begin{array}{l}\text { Labour } \\
\text { productivity } \\
\text { at the } \\
\text { regional } \\
\text { level - } \\
\text { Kirovohrad } \\
\text { region }\end{array}$ & $\begin{array}{l}\text { UAH/ } \\
\text { person }\end{array}$ & 15032,0 & 17840,0 & 21603,0 & 30409,0 & 30943,0 & 36524,0 & 46273,0 & 50855,0 & 58325,0 & 73531,0 & 99398,0 & 122494,0 & 140740,0 & 169346,0 & 154314,0 & 1026,6 \\
\hline $\begin{array}{l}\text { Labour } \\
\text { productivity } \\
\text { index at the } \\
\text { regional } \\
\text { level - } \\
\text { Kirovohrad } \\
\text { region }\end{array}$ & & 1,000 & 1,187 & 1,211 & 1,408 & 1,018 & 1,180 & 1,267 & 1,099 & 1,147 & 1,261 & 1,352 & 1,232 & 1,149 & 1,203 & 0,016 & 1,348 \\
\hline $\begin{array}{l}\text { Labour } \\
\text { productivity } \\
\text { in industry - } \\
\text { Kirovohrad } \\
\text { region }\end{array}$ & $\begin{array}{l}\text { UAH/ } \\
\text { person }\end{array}$ & 21053,0 & 26672,0 & 35886,0 & 46952,0 & 45447,0 & 62578,0 & 70200,0 & 78276,0 & 82629,0 & 100172,0 & 126693,0 & 173593,0 & 178344,0 & 218841,0 & 197788,0 & 939,5 \\
\hline $\begin{array}{l}\text { Index of } \\
\text { labour } \\
\text { productivity } \\
\text { in industry - } \\
\text { Kirovohrad } \\
\text { region }\end{array}$ & & 1,000 & 1,267 & 1,345 & 1,308 & 0,968 & 1,377 & 1,122 & 1,115 & 1,056 & 1,212 & 1,265 & 1,370 & 1,027 & 1,227 & $-0,04$ & $-3,157$ \\
\hline
\end{tabular}

Source: own study based on Main Department of Statistics in Kirovohrad region (2020) 


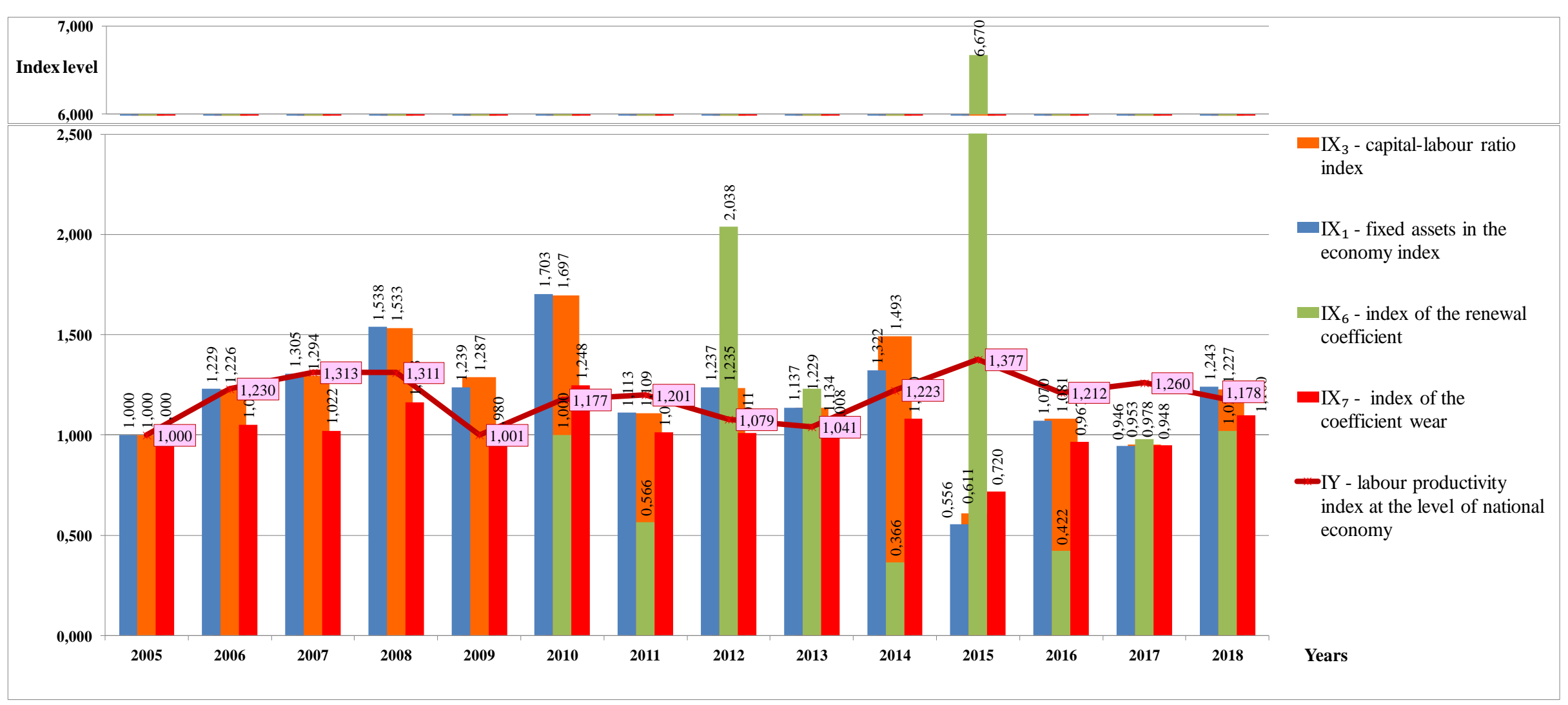

Fig. 1. The state of use of fixed capital (FC) at the level of the national economy during 2005-2018

Source: own study based on State Statistics Service of Ukraine (2020). 


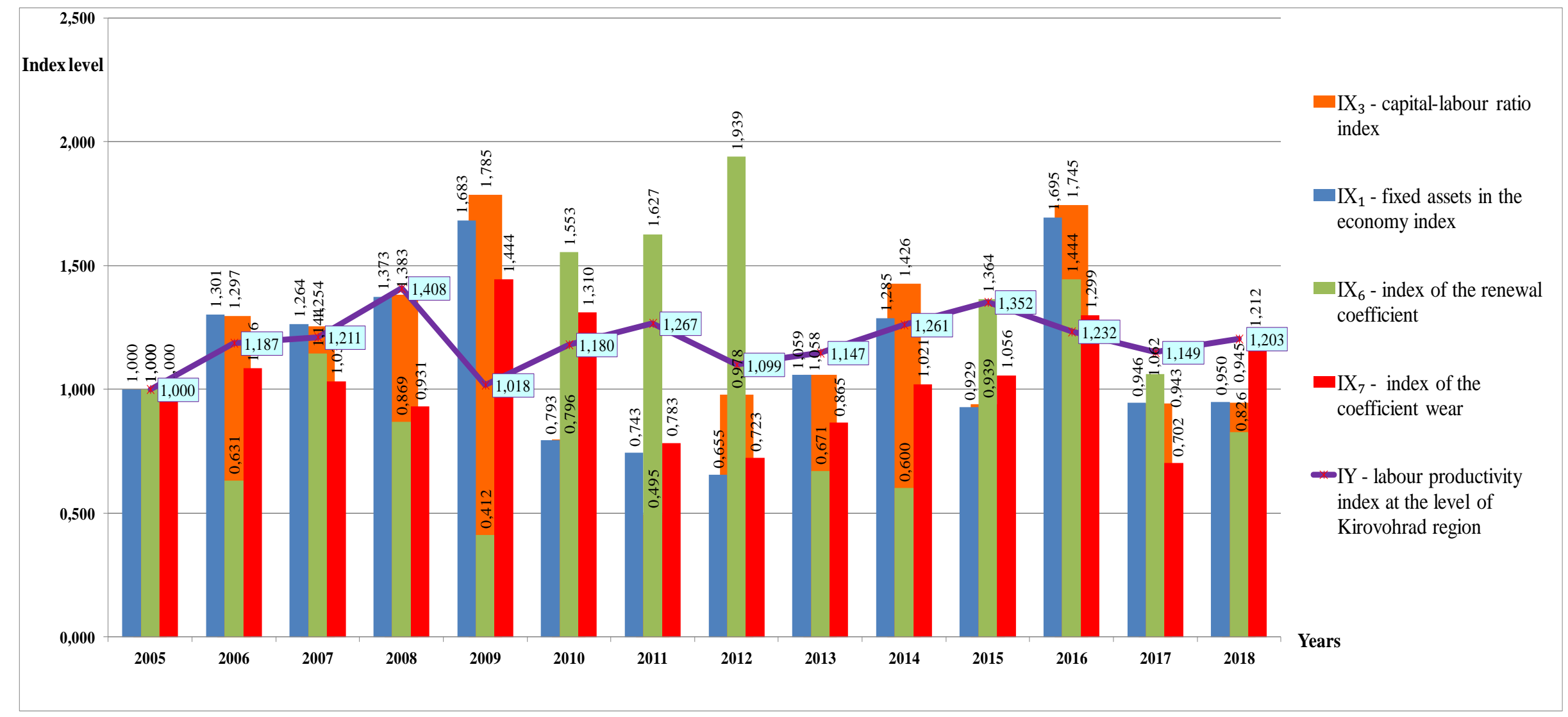

Fig. 2. The state of use of fixed capital (FC) at the level of Kirovohrad region during 2005-2018

Source: own study based on Main Department of Statistics in Kirovohrad region (2020) and State Statistics Service of Ukraine (2020). 
Thus, the coefficient of renewal of fixed assets in the economy of Ukraine in 2010-2018 increased by 1.9 percentage points, and on average for this period was $5.8 \%$.

In 2015, maximum values of the indices of renewal $\operatorname{IX}_{6}(6,670)$ and labour productivity $I Y(1,377)$ were recorded. This indicates the impact of technical and technological upgrades on the quantity and quality of products and services. The use of more productive and reliable means of labour, increasing technical level of production, increasing the use of production capacity; increasing output and improving product quality provides an increase in productivity.

In Kirovohrad region, the renewal coefficient of fixed assets during 2005-2018 decreased by 0.8 percentage points (from 6.5\% in 2005 to 5.7\% in 2018) (Main Department of Statistics in Kirovohrad region, 2020).

In economically developed countries, the renewal coefficient of fixed assets is $8.4-10 \%$. There is a need to launch into production fundamentally new equipment and materials, advanced technologies, machines and units of greater unit capacity and productivity, completed systems of complex mechanization and automation of production. Without urgent changes, there will no reproduction of fixed assets.

The influence of the following group of factors on labour productivity at the level of the national economy of Ukraine and Kirovohrad region (investment activity) is shown in Fig. 3 and 4. Thus, $\mathrm{X}_{9}$ - capital investments (investments in tangible and intangible assets) increased from 2005 (111174.0 million UAH) to 2018 (526341.8 million UAH) by $373.4 \%$. At the level of Kirovohrad region, capital investments $\mathrm{X}_{9}$ increased by $308.3 \%$ during $2005-2018$ (from 1572.6 million UAH to 6420.9 million UAH). But, despite such growth, the share of fixed capital investment in the total volume at the level of the national economy grew slowly and increased by only 5.7 percentage points over the last 14 years (from $83.7 \%$ to $89.4 \%$ ). In the economy of Kirovohrad region the share of fixed capital investment - $\mathrm{X}_{10}$ increased by 14.3 percentage points (from $81.7 \%$ in 2005 to $96.0 \%$ in 2018).

The reserves of labour productivity growth are negatively affected by the reduction of the share of investments in machinery, equipment and inventory to the total amount $\left(\mathrm{X}_{12}\right)$ at the national level by 5.2 percentage points $(2005-38.3 \%$ and $2018-33.1 \%)$. At the level of Kirovohrad region $\mathrm{X}_{12}$ has a slight increase from $37.5 \%$ (2005) to $47.3 \%$ (2018), by 9.8 percentage points. The final results of enterprise operation depend on investing in the material and technical base of production. It is not possible to achieve high productivity on obsolete equipment which constantly needs repair. Thus, index of the share of fixed capital investment at the national level $\left(\mathrm{IX}_{10}\right)$ for the last 14 years was the lowest in 2009 (0.919), which led to a decline in labour productivity index (IY) in 2009, which was also the lowest for the entire study period and amounted to 1.001 .

The share of investments in capital construction to the total volume at the national level $\left(\mathrm{X}_{11}\right)$ for 20052018 tends to decrease by 1.3 percentage points (from $45.5 \%$ to $44.2 \%$ ). In the economy of Kirovohrad region $\mathrm{X}_{11}$ also decreased by 13.1 percentage points (from $44.2 \%$ to $31.1 \%$ ). 
20 ACCESS Journal:

2021, 2(1), 50-77, https://doi.org/10.46656/access.2021.2.1(5)

\section{ISSN 2683-1007 (Online)}

https://journal.access-bg.org/

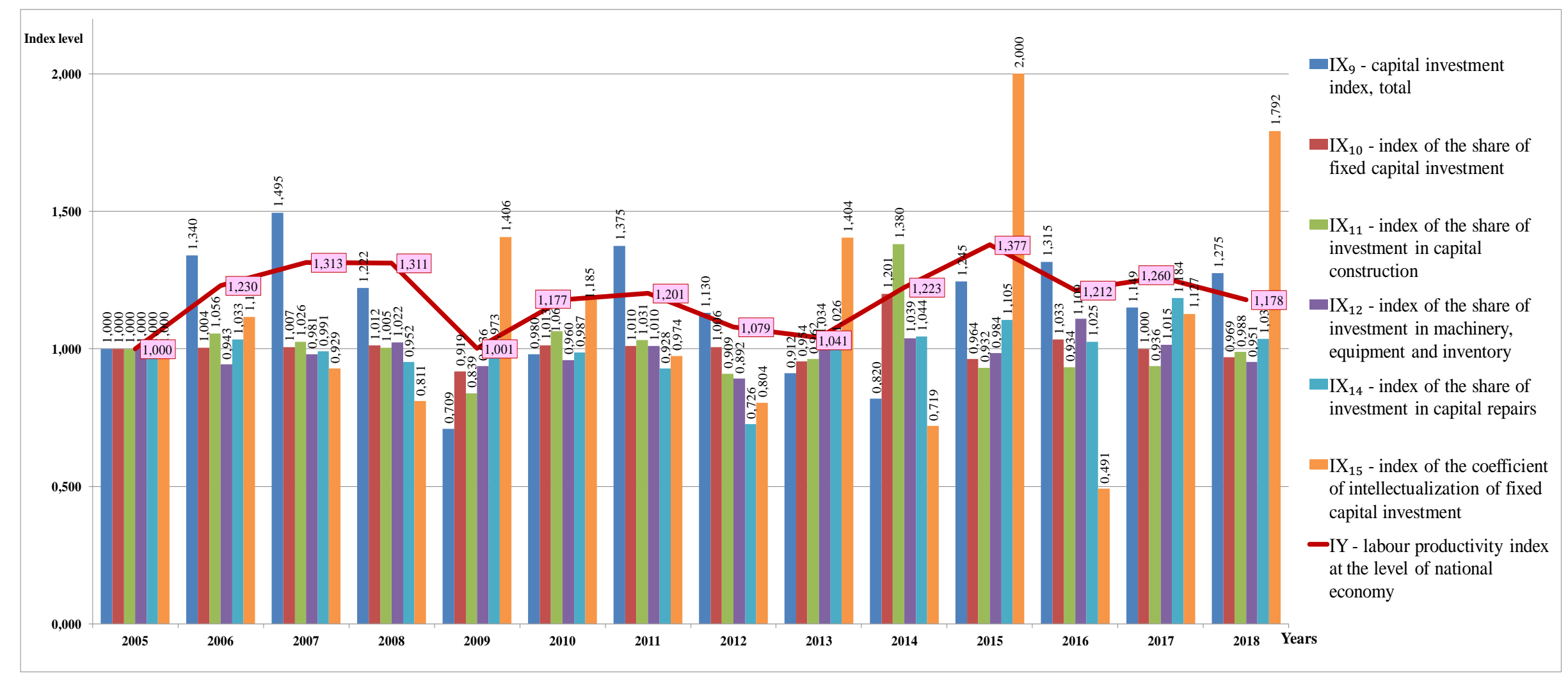

Fig. 3. Investment activity at the level of the national economy during 2005-2018 Source: own study based on State Statistics Service of Ukraine (2020). 
g. ACCESS Journal:

- 0 Access to Science, Business, Innovation in Digital Economy

2021, 2(1), 50-77, https://doi.org/10.46656/access.2021.2.1(5)

\section{ISSN 2683-1007 (Online)}

https://journal.access-bg.org/

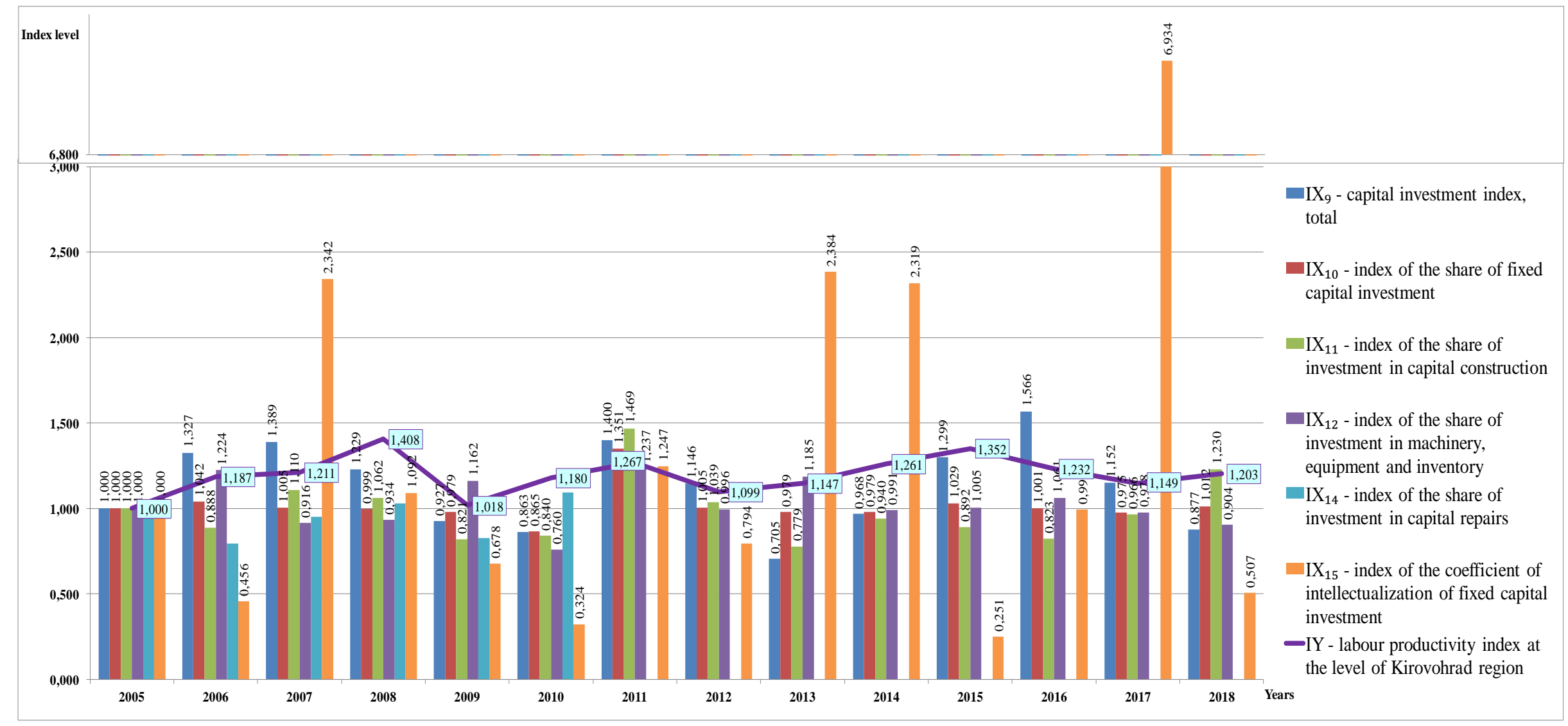

Fig. 4. Investment activity at the level of Kirovohrad region during 2005-2018

Source: own study based on Main Department of Statistics in Kirovohrad region (2020). 
We are talking about new capital construction, expansion, reconstruction of existing buildings and structures, carried out by contracts and economical methods.

The share of investments in capital repairs to the total amount $\left(\mathrm{X}_{14}\right)$ at the level of the national economy in 2005 was $10.4 \%$, and in 2018 (9.7\%) it decreased by 0.7 percentage points. In the economy of Kirovohrad region $\mathrm{X}_{14}$ also decreased by 4.7 percentage points from $15.8 \%$ (2005) to $11.1 \%$ (2010), and from 2011-2018 no investment was made in capital repairs. The method of partial reproduction was used, when worn-out equipment was replaced not by new, but by thoroughly repaired equipment.

The reliability indicators largely depend on the technical condition of the equipment and are significantly reduced after major repairs.

Investment intellectualization coefficient into fixed capital $\left(\mathrm{X}_{15}\right)$ shows the ratio of investments in intangible assets to fixed capital investment, that is the share of costs associated with software, databases; rights to commercial designations, objects of industrial property; copyright and related rights, patents, licenses, concessions, etc. The dynamics of the coefficient of intellectualization of fixed capital investment at the level of the national economy of Ukraine over the past 14 years is positive (Suvorova, Amelina, 2011). For example, in 2005 it was $3.2 \%$, and in 2018 it rose to $7.0 \%$. Thus, there is an increase of 3.8 percentage points. Maximum value of this indicator was 7.0\% (in 2015 and 2018). It was during this period of 2015 that the labour productivity index at the level of the national economy $(I Y)$ was the highest (1.377) for the last 14 years. This is explained by the fact that one of the powerful reserves for increasing labour productivity is the direction of investment in intangible fixed assets. At the level of Kirovohrad region $\mathrm{X}_{15}$ increased by 0.2 percentage points (from 1.0\% (2005) to $1.2 \%$ (2018).

The next group of factors influencing labour productivity at the level of the national economy of Ukraine and at the level of Kirovohrad region is the innovative activity of industrial enterprises (Fig. 5 and Fig.6). For the study, we chose the following factors (Golovanov, 2013):

$\mathrm{X}_{17}$ is the number of new technological processes (units) introduced into production;

$\mathrm{X}_{18}$ is the number of introduced innovative types of products, by names (units);

$X_{18 \_t e}$ is total expenditures on innovation activities (million $\mathrm{UAH}$ );

$X_{18 \_r d}$ is research and development (internal R\&D and external R\&D) (million UAH);

$X_{18 \_a t}$ is acquisition of new technologies (acquisition of other external knowledge) (million UAH);

$X_{18 \_a m}$ is acquisition of machinery, equipment and software (million UAH).

Among the above-mentioned factors of innovation, the total cost of innovation $X_{18}$ te is the greatest impact on productivity. At the level of the national economy of Ukraine it increased by $111.8 \%$, and at the level of Kirovohrad region by $348.8 \%$. Thus, in 2005-2018, the largest amount of expenditures on innovative activities of industrial enterprises of the national economy was in 2011 (14333.9 million UAH); in 2015 (13813.7 million UAH); in 2016 (23229.5 million UAH). 


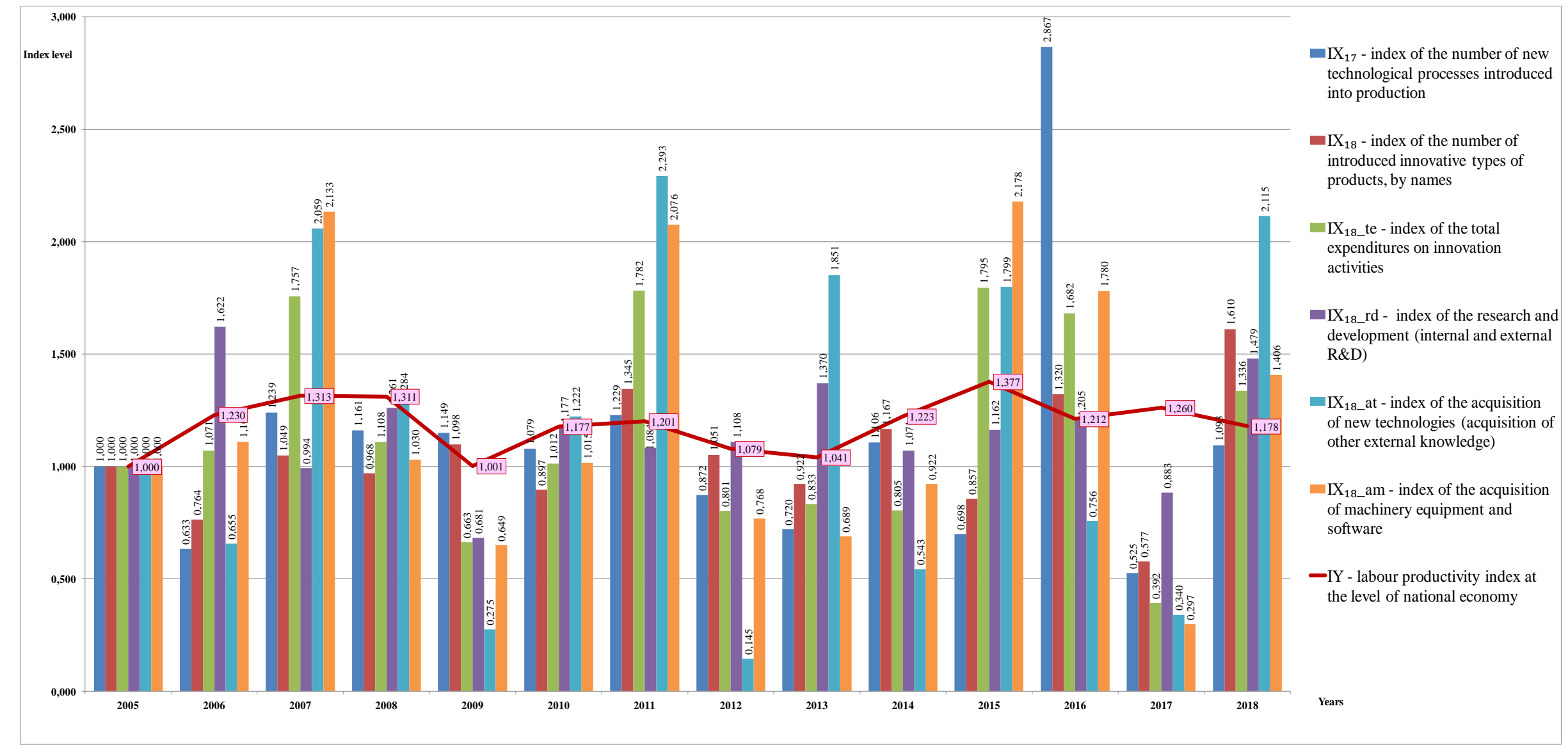

Fig. 5. Innovative activity of industrial enterprises at the level of the national economy during 2005-2018

Source: own study based on State Statistics Service of Ukraine (2020). 


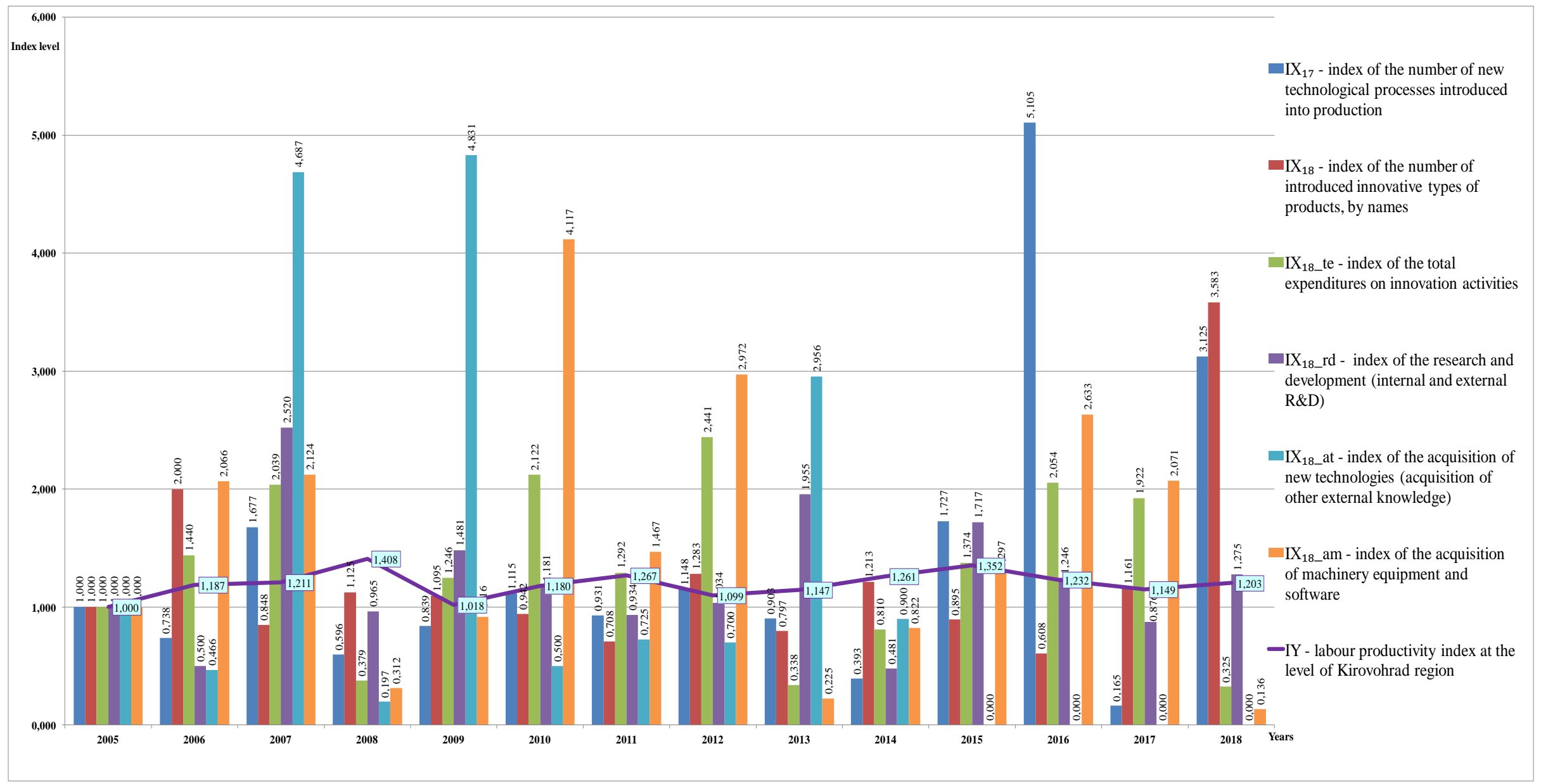

Fig. 6. Innovative activity of industrial enterprises at the level of Kirovohrad region during 2005-2018. Source: own study based on Main Department of Statistics in Kirovohrad region (2020). 
The index of total expenditures on innovation of the national economy $\left(X_{18}\right.$ te $)$ also reached its maximum in $2011-1.782$; in $2015-1.795$, which provided maximum growth of labour productivity index at the level of the national economy $(I Y)$ in $2011-1.201$ and in $2015-1.377$.

In the economy of Kirovohrad region, the largest amount of expenditures on innovation activities of industrial enterprises $\left(X_{18 \_t e}\right)$ for the period 2005-2018 was in 2012 (339.0 million UAH); in 2016 (262.3 million UAH); in 2017 (504.2 million UAH), which affected maximum value of labour productivity index at the level of Kirovohrad region $(I Y)$ in 2016 (1.232).

The study of the factor $X_{18}$ at which is acquisition of new technologies (acquisition of other external knowledge) at the level of the national economy of Ukraine shows that in 2007, 2008, 2011 and 2015 was the largest funding for the acquisition of new technologies (respectively 328.4 million UAH; 421.8 million UAH; 324.7 million UAH; 84.9 million UAH).

The factor $X_{18 \_a m}$ which is the purchase of machinery equipment and software in the national economy also had the highest figures in 2007, 2008, 2011, 2015 and 2016 (respectively, 7441.2 million UAH; 7664.8 million UAH; 10489.1 million UAH; 11141.3 million UAH; 19829.0 million UAH).

The influence of the above-mentioned factors led to maximum values of labour productivity index at the level of the national economy $(I Y)$ in the same period, so in $2007-1.313$; in $2011-1.201$; in $2015-1.377$.

Next group of factors "Use of working time" at the levels of the national economy of Ukraine and Kirovohrad region should be considered with the help of indices (Fig. 7 and Fig.8). During the period of 2008-2015 in 2009, labour productivity index at the level of the national economy was the lowest and amounted to $I Y=1.001$, which was influenced by rapid growth of the index of the indicator of losses of working time fund by $207.45 \%$ ( $\left.\mathrm{IX}_{19}-3.074\right)$. Among the reasons for the increase in loss of working time in 2009 should be noted an increase in time due to absenteeism due to transfer to a reduced working day or week by $238.5 \%$ ( $\left.\mathrm{IX}_{24}-3.385\right)$ and an increase in time due to absenteeism with the permission of administration by $66.7 \%\left(\mathrm{IX}_{23}-1.667\right)$. The result of the loss of working time in 2009 was the global financial and economic crisis of 2008-2009.

Among factors influencing the increase in labour productivity index at the level of the national economy in $2011(I Y-1.201) ; 2014(I Y-1.223)$ and 2015 (IY - 1.377) are the following, where there was a decrease in loss of working time compared to 2008:

- due to annual leave $\operatorname{IX}_{20}$ (in 2010 by $1.2 \%$; in $2015-2.4 \%$ );

- due to temporary disability status $\mathrm{IX}_{21}$ (in 2011 by $12.0 \%$; in $2014-9.5 \%$ );

- due to studies, vacations and other absences $\operatorname{IX}_{22}$ (in 2011 by $27.3 \%$; in $2015-9.1 \%$ );

- due to absences in connection with the transfer to a reduced working day or week $\operatorname{IX}_{24}$ (in 2011 by $45.5 \%$; in $2015-15.4 \%$ ).

The influence of the factors "Use of working time" on labour productivity at the level of Kirovohrad region has the same patterns as at the level of the national economy of Ukraine. 


\section{Q. ACCESS Journal:}

-10 Access to Science, Business, Innovation in Digital Economy

2021, 2(1), 50-77, https://doi.org/10.46656/access.2021.2.1(5)

\section{ISSN 2683-1007 (Online)}

https://journal.access-bg.org/

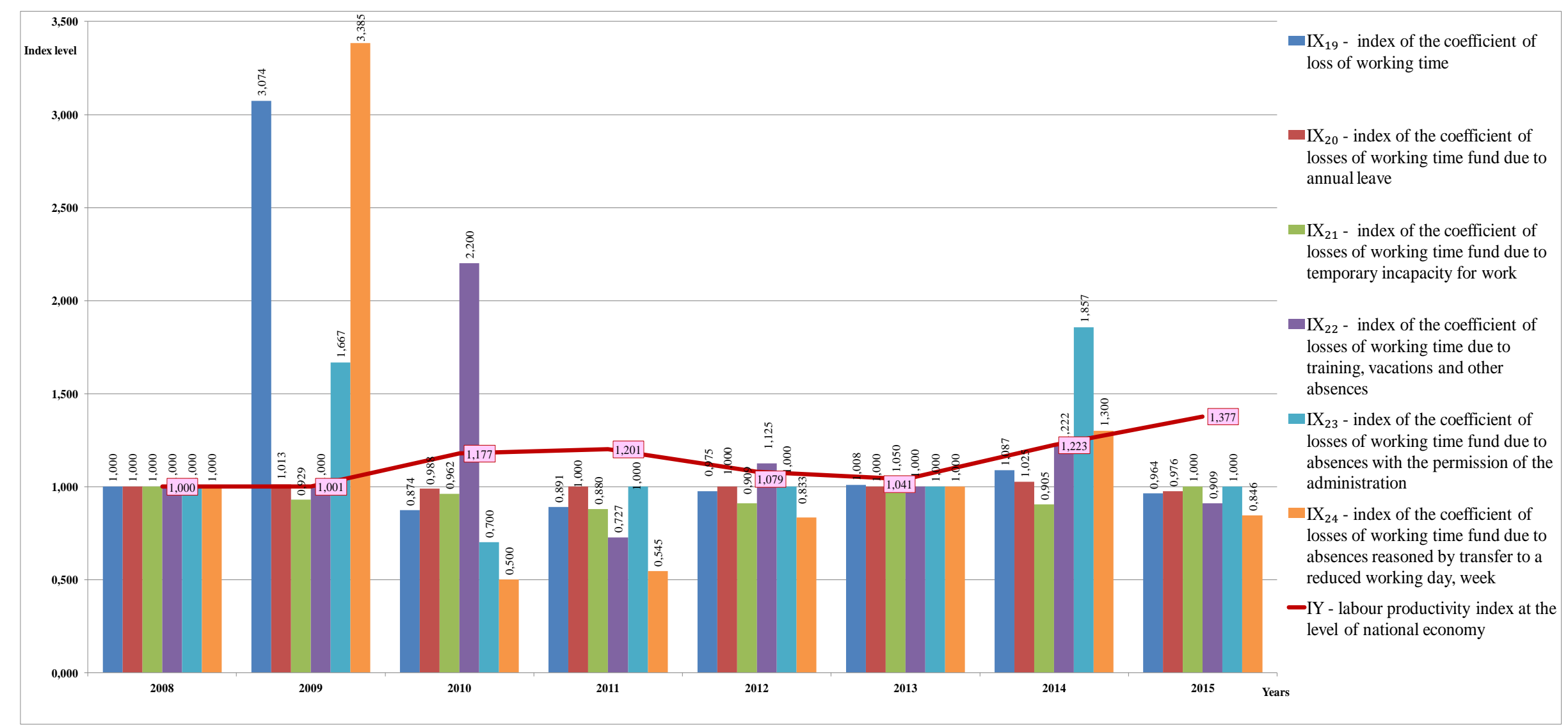

Fig. 7. The use of working time at the level of the national economy during 2008-2015

Source: own study based on State Statistics Service of Ukraine (2020). 


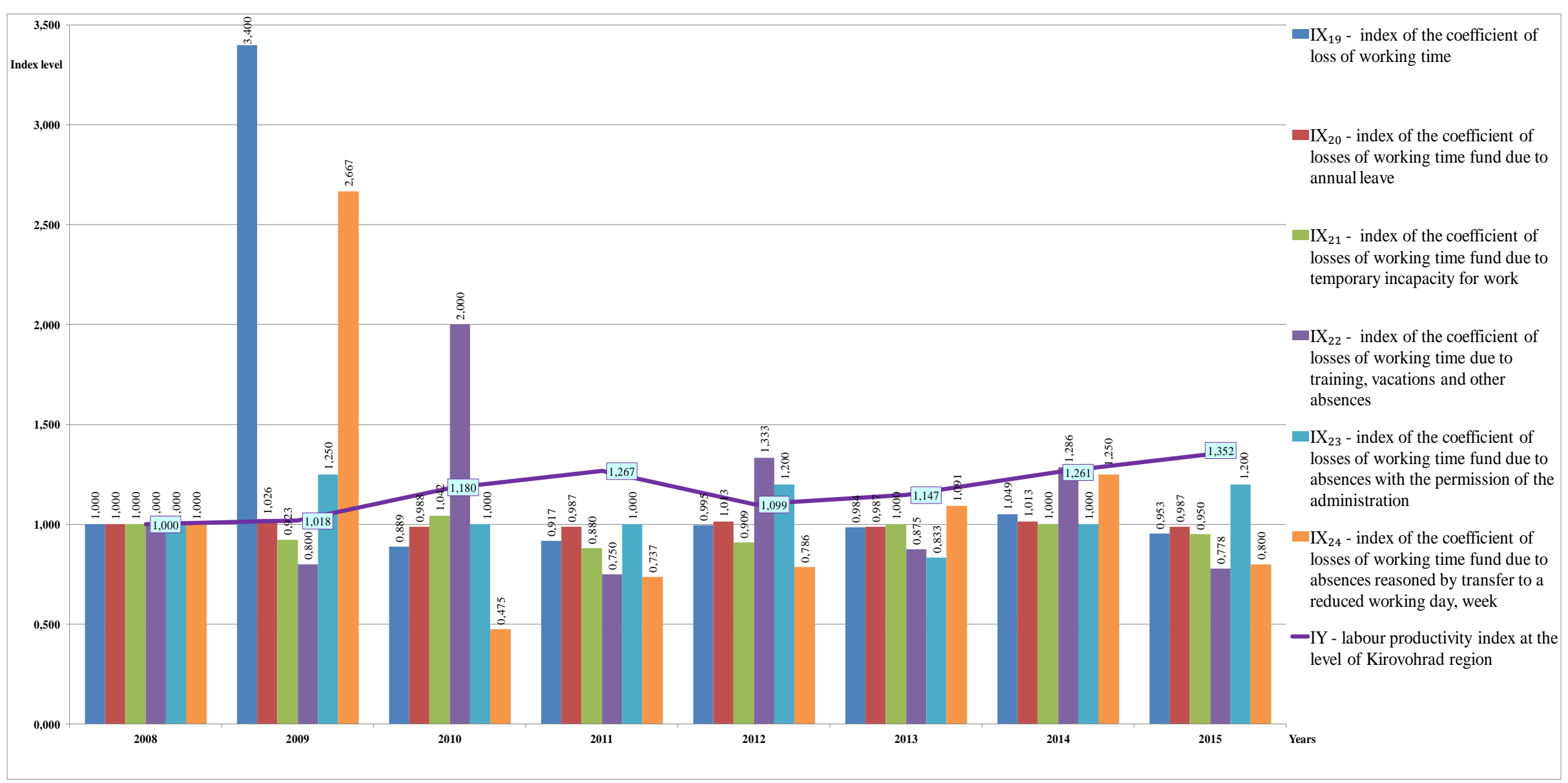

Fig. 8. Use of working time at the level of Kirovohrad region during 2008-2015

Source: own study based on Main Department of Statistics in Kirovohrad region (2020) 
Thus, for the period of 2008-2015 in 2009 the index of labour productivity at the level of Kirovohrad region was the lowest and amounted to $I Y=1.018$.

This was influenced by rapid growth of the index of the coefficient of the loss of working time by $240.0 \%$ $\left(\mathrm{IX}_{19}\right.$ - 3.4). Among the reasons for the increase in working time losses in 2009 should be noted the increase in time due to absenteeism due to transfer to a reduced working day or week by $166.7 \%\left(\mathrm{IX}_{24}-2.667\right)$ and an increase in time due to absenteeism with the permission of administration by $25.0 \%\left(\mathrm{IX}_{23}-1.250\right)$.

This year was an exception to identify patterns in connection with the global financial and economic crisis of 2008-2009.

Among factors influencing the increase in labour productivity index at the level of Kirovohrad region in 2011 (IY - 1.267); $2014(I Y-1.261)$ and 2015 (IY - 1.352) are the following, where there was a decrease in loss of working time compared to 2008:

- due to annual leave $\mathrm{IX}_{20}$ (in 2011 by $1.3 \%$; in $2015-1.3 \%$ );

- due to temporary disability status $\mathrm{IX}_{21}$ (in 2011 by $12.0 \%$, in $2015-5.0 \%$ );

- due to studies, vacations and other absences IX 22 (in 2011 by $25.0 \%$; in $2015-22.2 \%$ );

- due to absences with the permission of administration $\operatorname{IX}_{23}$ (in 2013 by 16.7\%);

- due to absences in connection with transfer to a reduced working day or week $\operatorname{IX}_{24}$ (in 2011 by 26.3\%; in $2015-20.0 \%)$.

Thus, reducing the loss of working time for reasons that do not depend on the workforce, is a reserve to increase production, which does not require additional investment and allows getting a quick return.

The study of the influence of the factors "Composition of the payroll budget" on labour productivity at the levels of the national economy of Ukraine and Kirovohrad region should be considered with the help of indices.

During 2008-2018, labour productivity index at the level of the national economy $(I Y)$ had minimal values. So in 2009 it was 1.001 and in 2013 it was 1.041. Accordingly, during this period there was a decrease in incentive and compensation payments $\left(\mathrm{IX}_{27}\right)$ by $8.6 \%$ in 2009 and by $2.0 \%$ in 2013; reduction of additional wages in the payroll budget ( $\left.\mathrm{IX}_{26}\right)$ by $0.6 \%$ in 2009 and basic wages in the payroll budget $\left(\mathrm{IX}_{25}\right.$ ) by $1.2 \%$ in 2013 .

Labour productivity index at the level of Kirovohrad region $(I Y)$ in the period of 2008-2018 had the lowest values, in $2009-1.018$ and in $2012-1.099$ respectively. Thus, such a decline was also caused by a decrease in incentive and compensation payments $\left(\mathrm{IX}_{27}\right)$ by $12.9 \%$ and additional wages in payroll budget (IX ${ }_{26}$ ) by $0.2 \%$ in 2009 and by $2.6 \%$ in 2012 .

There were natural trends in increasing labour productivity at the level of the national economy with the growth of additional wages in payroll budget $\left(\mathrm{IX}_{26}\right)$ in 2011 by $1.8 \%$; in $2014-3.0 \%$; in $2015-9.4 \%$; in $2017-1.5 \%$ and an increase in incentive and compensation payments ( $\left.\mathrm{IX}_{27}\right)$ in 2010 by $7.4 \%$; in $2014-$ $15.6 \%$; in $2017-14.3 \%$. The increase in labour productivity at the level of Kirovohrad region was also 
influenced by the growth of additional wages in payroll budget $\left(\mathrm{IX}_{26}\right)$ in 2011 by $1.0 \%$; in $2014-3.0 \%$; in $2015-13.1 \%$; in $2018-3.9 \%$.

The factor of instability of economic development, both at the levels of the national economy of Ukraine and Kirovohrad region is that the growth rate of the average monthly wage exceeded the growth rate of labour productivity. Thus, labour productivity index at the level of the national economy $(I Y)$ in 2009 was 1.001 ; in 2012 - 1.079; in 2013 - 1.041; in 2016 - 1.212; in $2017-1.260$ and in 2018 - 1.178. At the same time, the index of the average monthly nominal wage per employee $\left(\operatorname{IX}_{29}\right)$ in 2009 was 1.055 ; in 2012 1.149; in 2013 - 1.079; in 2016 - 1.236; in 2017 - 1.371 and in 2018 - 1.248. Labour productivity index at the level of Kirovohrad region (IY) in 2009 amounted to 1.018; in 2012 - 1.099; in $2017-1.149$ and in 2018 - 1.203 and had a reduced difference between the indices of the average monthly nominal wage per employee ( $\mathrm{IX}_{29}$ ), which amounted to 1.076 in 2009; in $2012-1.149$; in $2017-1.457$ and in $2018-1.242$.

Constant excess of wages over productivity, in particular the average monthly wage, leads to a disparity between social and macroeconomic indicators. Under conditions of outpacing growth of labour productivity, certain accumulations are necessary for the development of production and production of competitive products, meeting socio-economic needs of staff (Turchina, 2013).

In the study of the group of factors "Formation and use of personnel" on the growth of labour productivity at the level of the national economy for 2005-2018 (Fig. 9 and Fig. 10), the most influential are the following (Chernushkina, 2013); Yarchuk, Sinyaeva, 2014):

- the index of the coefficient "Advanced training of the average number of full-time employees" $\left(\mathrm{IX}_{32}\right)$ had a tendency to increase in 2007 by $7.9 \%$, in $2010-5.0 \%$, in $2011-5.6 \%$;

- the index of the coefficient "Trained to new professions in relation to the average number of full-time employees" $\left(\mathrm{IX}_{36}\right.$ ) also had a growth dynamics, so in 2007 by $2.8 \%$, in $2010-2.4 \%$, in $2011-8.3 \%$ (due to the abolition of the Form № 6-PV (annual) "Report on the number of employees, their quality and professional training", The Order of the State Statistics Service №260 dated 30.09.2015, further to study the impact of training and education to new professions in relation to the average number of full-time employees on labour productivity (since 2015 and to date there is no possibility);

- index of the share of the employed population with full higher education (Master's degree or qualification level of Specialist) ( $\mathrm{IX}_{31}$ ) increased in 2006 by $3.7 \%$, in 2007 by $2.9 \%$, in 2010 by $4.5 \%$, in 2014 by $11.8 \%$, in $2015-2.4 \%$, in $2017-2.3 \%$, which increased labour productivity at the level of the national economy;

- index of the share of the employed population with basic higher education (Bachelor's degree) $\left(I \mathrm{X}_{30}\right)$ reached its maximum values and increased in 2010 by $23.8 \%$, in $2014-19.1 \%$, in $2015-9.1 \%$, which also ensured growth of labour productivity. 


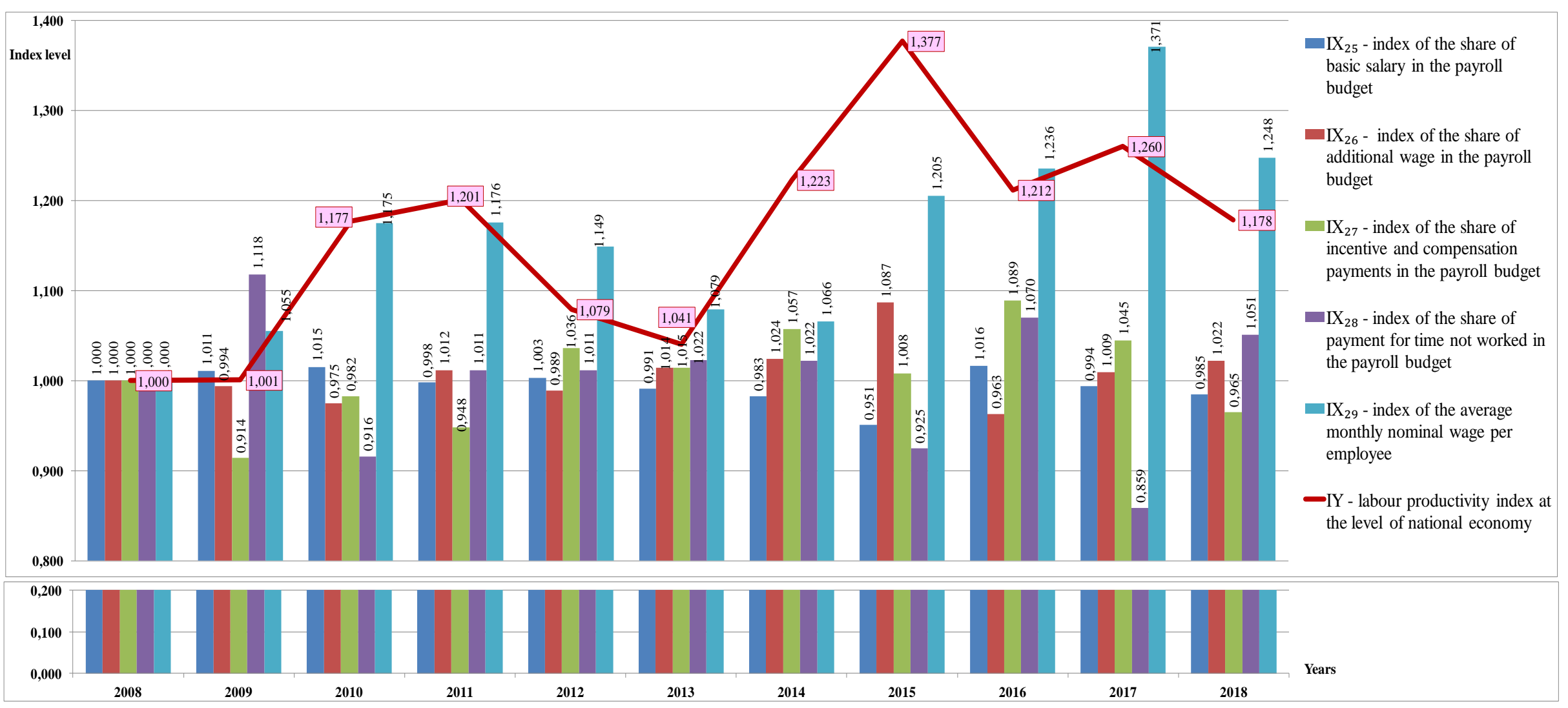

Fig. 9. Composition of payroll budget at the level of the national economy during 2008-2018 Source: own study based on State Statistics Service of Ukraine (2020). 


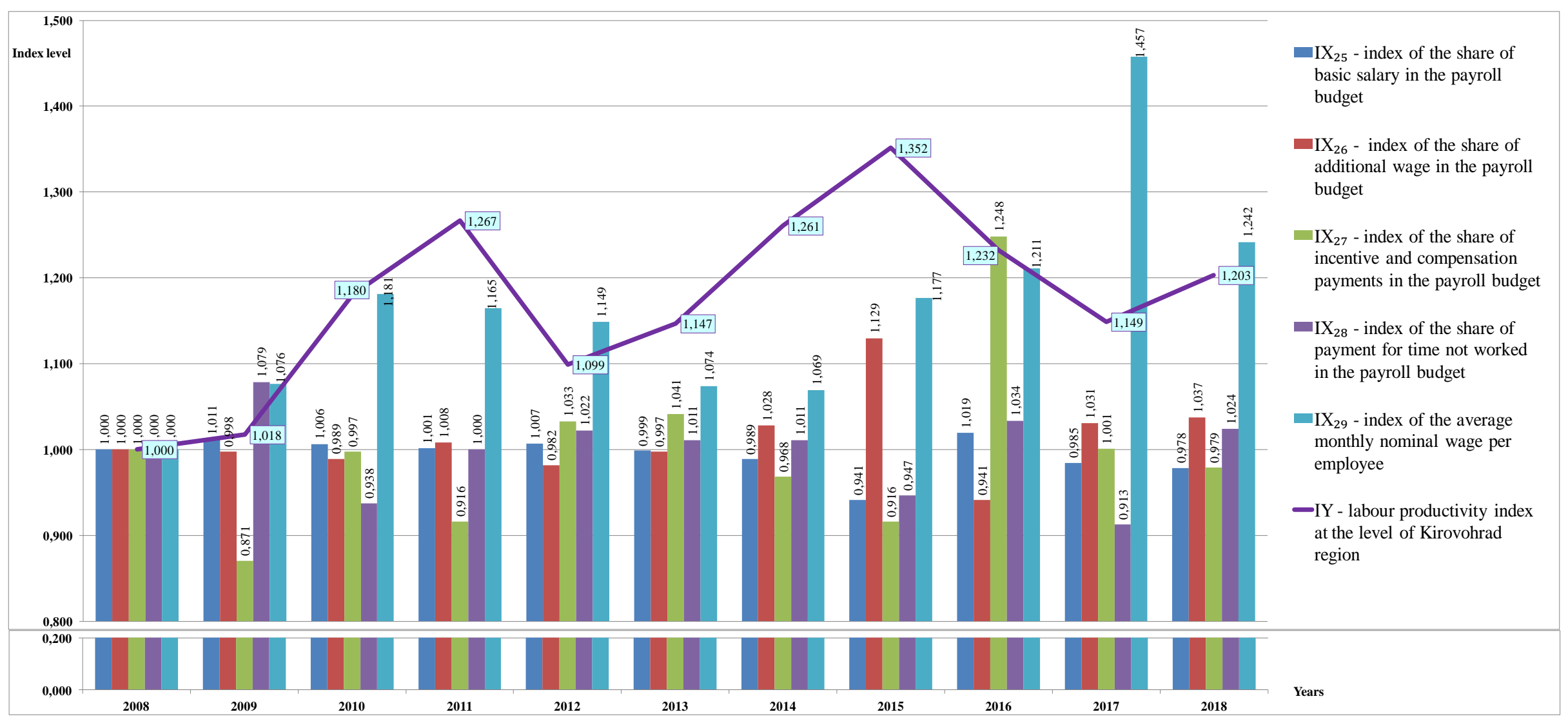

Fig. 10. Composition of payroll budget at the level of Kirovohrad region during 2008-2018.

Source: own study based on Main Department of Statistics in Kirovohrad region (2020). 
At the level of Kirovohrad region, factors that ensured the increase in labour productivity during 20052018 were the same as at the national level from the group "Formation and use of personnel":

- index of the coefficient of advanced training of the average number of full-time employees $\left(\mathrm{IX}_{32}\right)$ tended to increase in 2006 by $11.9 \%$, in $2007-8.6 \%$, in $2011-7.9 \%$, in $2014-3.7 \%$;

- index of the coefficient "Trained in new professions in relation to the average number of full-time employees" ( $\mathrm{IX}_{36}$ ) also had a growth dynamics, so in 2008 by $6.0 \%$, in $2011-25.5 \%$, in $2013-35.0 \%$;

- index of the share of the employed population with a complete higher education (Master's degree or qualification level of Specialist) ( $\left.\mathrm{IX}_{31}\right)$ increased in 2007 by $2.9 \%$, in 2008 by $0.6 \%$, in 2010 by $9.5 \%$, in 2014 by $12.7 \%$, in 2015 by $9.9 \%$ and in 2018 by $5.0 \%$.

- index of the share of the employed population with basic higher education (Bachelor's degree) $\left(I \mathrm{X}_{30}\right)$ increased in 2010 by $23.8 \%$, in $2013-19.1 \%$, in $2015-9.1 \%$, in $2017-33.6 \%$, which also ensured the growth of labour productivity.

- index of the share of the employed population with basic higher education (Bachelor's degree) $\left(I \mathrm{X}_{30}\right)$ increased in 2010 by $23.8 \%$, in $2013-19.1 \%$, in $2015-9.1 \%$, in $2017-33.6 \%$, which also ensured the growth of labour productivity.

At the level of Kirovohrad region, factors that ensured the increase in labour productivity during 20052018 were the same as at the national level from the group "Formation and use of personnel" (Fig. 11 and Fig. 12):

- index of the coefficient of advanced training of the average number of full-time employees ( $\mathrm{IX}_{32}$ ) tended to increase in 2006 by $11.9 \%$, in $2007-8.6 \%$, in $2011-7.9 \%$, in $2014-3.7 \%$;

- index of the coefficient "Trained in new professions in relation to the average number of full-time employees" ( $\mathrm{IX}_{36}$ ) also had a growth dynamics, so in 2008 by $6.0 \%$, in $2011-25.5 \%$, in $2013-35.0 \%$;

- index of the share of the employed population with a complete higher education (Master's degree or qualification level of Specialist) $\left(\mathrm{IX}_{31}\right)$ increased in 2007 by $2.9 \%$, in 2008 by $0.6 \%$, in 2010 by $9.5 \%$, in 2014 by $12.7 \%$, in 2015 by $9.9 \%$ and in 2018 by $5.0 \%$. 


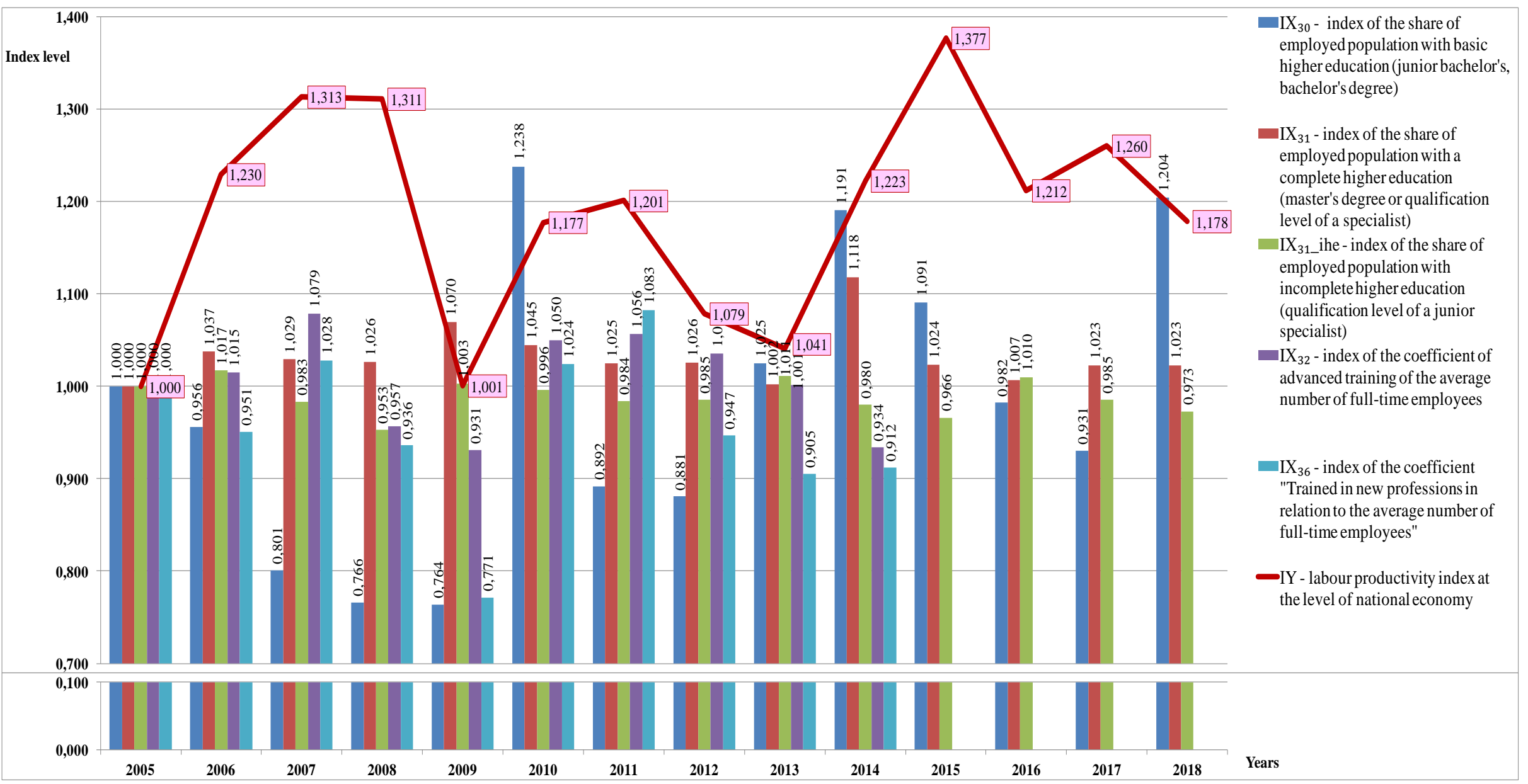

Fig. 11. Formation and use of personnel at the level of the national economy during 2005-2018

Source: own study based on State Statistics Service of Ukraine (2020). 


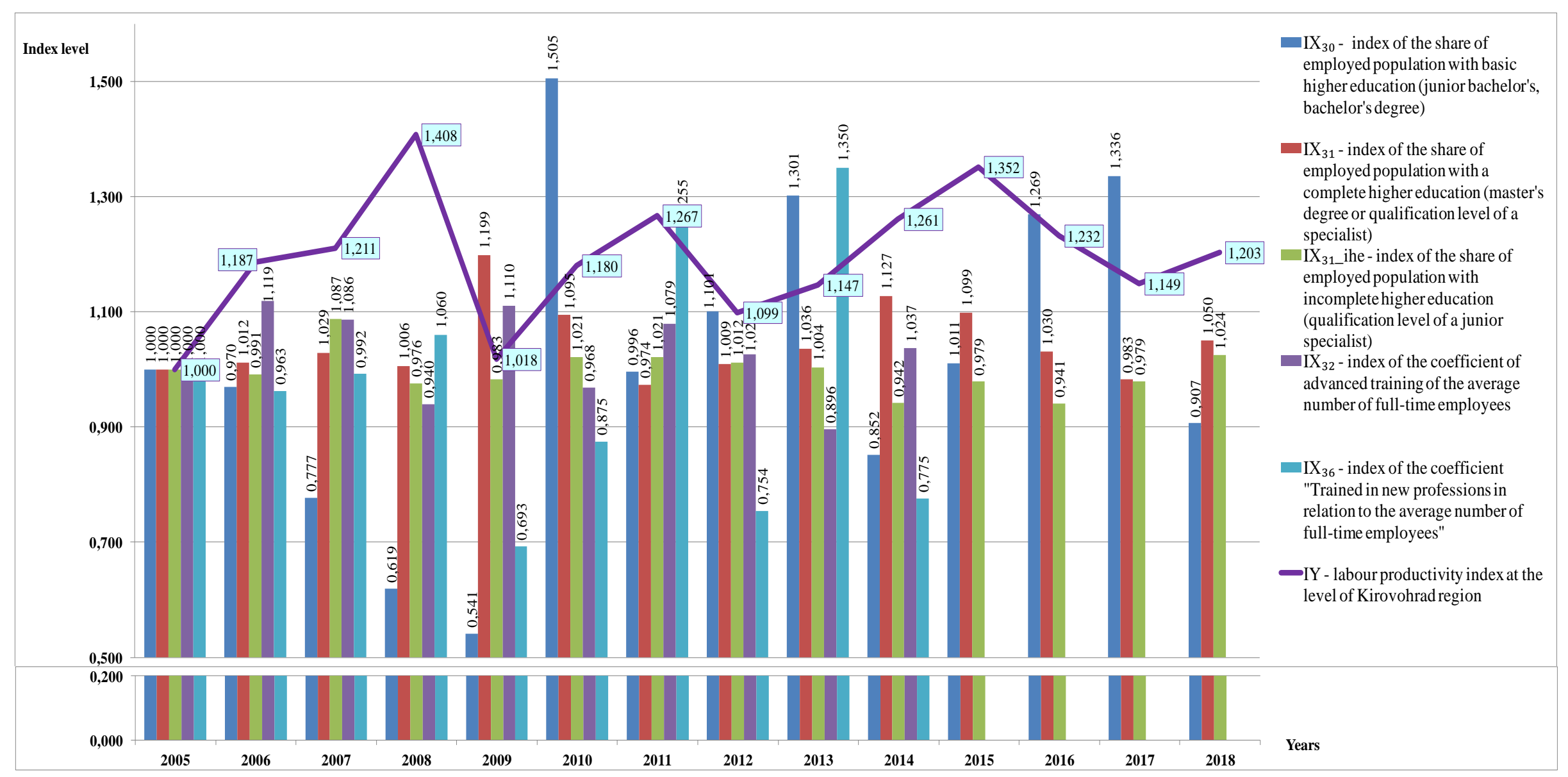

Fig. 12. Formation and use of personnel at the level of Kirovohrad region for 2005-2018

Source: own study based on Main Department of Statistics in Kirovohrad region (2020). 


\section{CONCLUSIONS}

1. The results of the research have shown that at macro-, mesoeconomic levels there are significant reserves for labour productivity growth by increasing technical level of production, efficient investment and innovation activities, improving the use of working time with minimizing losses, changes in production, labour and management, material incentives and raising educational and qualification levels.

2. It is established that in the group of factors "The state of use of fixed capital (FC)" are those that increase labour productivity. Particularly, "Renewal coefficient of fixed assets in the economy of Ukraine" during 2010-2018 increased by 1.9 percentage points, and the average for this period was $5.8 \%$. In 2015 , maximum values of the indices of the coefficient of renewal $I \mathrm{X}_{6}$ were recorded at 6.670 and labour productivity $I Y$ at 1.377 , which indicates the impact of technical and technological renewal on the quantity and quality of products and services. The use of more productive and reliable means of labour, increasing technical level of production and the use of production capacity, increasing output and improving product quality provides increase in labour productivity.

3. It is proved that in the group of factors "Investment activity" one of the powerful reserves to increase labour productivity is the direction of investment in intangible assets of fixed capital. Thus, the coefficient of intellectualization of fixed capital investments at the level of the national economy of Ukraine for the last 14 years has a positive impact. For example, in 2005 it was $3.2 \%$, and in $2018-7.0 \%$, that is there is an increase of 3.8 percentage points. At the level of Kirovohrad region $\mathrm{X}_{15}$ it increased by 0.2 percentage points from $1.0 \%$ (2005) to $1.2 \%$ (2018).

4. It is established that in the group of factors "Innovative activity" the influence on increase of labour productivity during 2005-2018 has $X_{18}$ te which is the total volume of expenses for innovative activity that at the level of national economy of Ukraine grew by $111.8 \%$, and at the level of Kirovohrad region - by $348.8 \%$. Namely, the acquisition of new technologies (acquisition of other external knowledge) at the level of the national economy of Ukraine shows that in 2007, 2008, 2011 and 2015 there was the largest funding (respectively 328.4 million UAH; 421.8 million UAH; 324.7 million UAH; 84.9 million UAH). Purchase of machinery, equipment and software in the national economy also had the highest figures in 2007, 2008, 2011, 2015 and 2016, respectively, 7441.2 million UAH; 7664.8 million UAH; 10489.1 million UAH; 11141.3 million UAH; 19829.0 million UAH, which ensured the growth of labour productivity index at the level of the national economy $(I Y)$ in 2007 - 1.313; in $2011-1.201$; in $2015-1.377$.

5. It is analyzed that among factors of the group "Use of working time" that affect the increase in labour productivity index at the level of the national economy in 2011 (IY - 1.201); 2014 (IY - 1.223) and 2015 (IY 1.377) and at the level of Kirovohrad region in 2011 (IY - 1.267); $2014(I Y-1.261)$ and 2015 (IY - 1.352) are a reduction in the loss of working time due to annual leave; temporary disability; studies, vacations and other absences; absences with the permission of administration; absences in connection with transfer to a reduced working day or week. Thus, reducing loss of working time for reasons that do not depend on the workforce is 
a reserve to increase production, which does not require additional investment and allows getting a quick a return.

6. It is proved that in the group of factors "Composition of the payroll budget" the decrease in incentive and compensation payments $\left(\mathrm{IX}_{27}\right.$ ) and additional wages in the payroll budget ( $\mathrm{IX}_{26}$ ) for 2008-2018 led to a decline in labour productivity index at the level of national economy $(I Y)$ in $2009-1.001$ and in $2013-$ 1.041 and labour productivity index at the level of Kirovohrad region $(I Y)$, respectively, in $2009-1.018$ and in $2012-1.099$.

7. It is established that influential factors from the group "Formation and use of personnel" on labour productivity growth at the level of the national economy and at the level of Kirovohrad region for 2005-2018 are: index of the coefficient of advanced training of the average number of full-time employees $\left(\mathrm{IX}_{32}\right)$; index of the coefficient "Trained in new professions in relation to the average number of full-time employees" $\left(\mathrm{IX}_{36}\right)$; index of the share of the employed population with a complete higher education (Master's degree or qualification level of Specialist) $\left(\mathrm{IX}_{31}\right)$ and index of the share of the employed population with a basic higher education (Bachelor's degree) $\left(I \mathrm{X}_{30}\right)$.

\section{Conflict of interests}

The authors declare no conflict of interest.

\section{References}

Bacho, R., Pukala, R., Hlibko, S., Vnukova, N.,\& Pola, P. (2019). Information management: The key driver of the economic system's development. Marketing and Management of Innovations, 3, $297-307$. https://doi.org/10.21272/mmi.2019.3-23

Baklanova, O., Petrova, M., Koval, V. (2020). Institutional Transmission in Economic Development. Ikonomicheski Izsledvania, 29(1), 68-91.

Chernushkina, O.O. (2013). Labour productivity in Ukraine: comparative aspect. Research and Production Journal "Innovative Economy", 9 (47). 106-113.

Golovanov, A.I. (2013). From productivity to labour efficiency. Bulletin of Tomsk State University, 376. $137-141$.

Korneeva, T.S. (2015). Study of the influence of factors of development of the national economy of Ukraine on labour efficiency. Administrarea Publică. Academia de Administrare Publică, $3 \quad$ (87). $108-114$. http://aap.gov.md/files/publicatii/revista/15/3.pdf.

Lazarova, T., Zhelyazkova, V., Vazov, R. (2015). Innovation leadership as a key concept in entrepreneurship. Proceedings of International Conference for Entrepreneurship, Innovation and Regional Development ICEIRD 2015, University of Sheffield, pp.275-287

Main Department of Statistics in Kirovohrad region (2020). Retrieved from http://www.kr.ukrstat.gov.ua/

Ministry of Economic Development and Trade of Ukraine (2019). Methodical recommendations for calculating the resource intensity of gross domestic product by main groups of resources, labour productivity, return on fixed assets at the level of national economy, regional level and by type of economic activity. (Order of the Ministry of Economic Development and Trade of Ukraine dated 06.06.2019 № 965). https://www.me.gov.ua/Documents/List?lang=uk-UA\&tag=MetodichniRekomendatsii.

Naama, K. (2001). International Movement of Foreign Direct Investments. Economic Thought journal, Bulgarian Academy of Sciences - Economic Research Institute, 5, 81-92. https://www.ceeol.com/search/articledetail?id=221618 
Ocheredco, O. (2020). The improvement of the investment attractiveness of industrial enterprises in the convention of the COVID-19 pandemic. Access: Access to science, business, innovation in digital economy, ACCESS Press, 1(2): 131-145, https://doi.org/10.46656/access.2020.1.2(5)

Petrova, M., Koval, V., Tepavicharova, M., Zerkal, A., Radchenko, A., \& Bondarchuk, N. (2020). The interaction between the human resources motivation and the commitment to the organization. Journal of Security and Sustainability Issues, 9(3), 897-907. https://doi.org/10.9770/jssi.2020.9.3(15)

Pogorelova, T.O. (2016). Analysis of factors that affect the efficiency of the enterprise staff. Bulletin of the National Technical University "Kharkiv Polytechnic Institute". Economic sciences. Kharkiv: NTU "KhPI", 27 (1199). 1721.

Potudanskaya, V.F., Karkoshkina, A.M. (2013). Technical and technological innovations as a key factor in improving labour efficiency in industry. Omsk Scientific Bulletin. Sociological and economic sciences, 2 (116). 53-57.

Radukanov, S. (2014) Study of the resource efficiency of banks in Bulgaria, Annual Doctoral Research Almanac, D. A. Tsenov Academy of Economics Vol. 7, 323-349

Semiv, L.K. (2013). Theoretical and applied aspects of the impact of knowledge and innovation on labour productivity. Efficient economy. Electronic scientific professional publication. Dnipropetrovsk state agrarian and economic university, 9. http://www.economy.nayka.com.ua/?op=1\&z=2317.

Semykina, M.V. (2010). Labour productivity: measurement methodology, prerequisites for growth. Scientific works of KNTU. Economic sciences, 17. 457-464.

Serhiychuk, S.I. (2011). Productivity management in mechanical engineering. [Abstract of dissertation for PhD in Economics: 08.00.07]. Donetsk National University. Donetsk, 257.

State Statistics Service of Ukraine (2020). Retrieved from http://www.ukrstat.gov.ua/

Suvorova, V.V., Amelina, N.V. (2011). Modern aspects of ensuring and evaluating labour efficiency in production systems (on the example of chemical industry). Bulletin of SSTU. Economics. Saratov, 4 (59), 1. 258-264.

Turchina, V.M. (2013). Organizational and economic mechanism of labour efficiency management. [Abstract of dissertation for PhD in Economics: 08.00.07]. Kyiv, 24.

Vazov R. (2019). Inovative Approaches to Insurance Company Cash Flow Management (contemporary theoretical aspects). Sofia: VUZF Publishing House "St. Grigorii Bogoslov", ISBN: 978-954-8590-54-9, 136 p.

Vorobyova, L.D., \& Odintsov, M.M. (2015). Optimization of the mechanism of management of labour efficiency of company employees. Bulletin of Khmelnytskyi National University. Economic sciences, 1. 72-77.

World Bank (2020). Retrieved from https://data.worldbank.org/indicator/NY.GDP.MKTP.PP.CD?locations=UA.

Yarchuk, A.V., Sinyaeva, L.V. (2014). Labour productivity as a factor influencing competitiveness of Ukraine's economy. Economics and organization of management. Bulletin of Donetsk National University, 2. 80-83.

Yankovyi, O., Goncharov, Yu., Koval, V., \& Lositska, T. (2019). Optimization of the capital-labor ratio on the basis of production functions in the economic model of production. Naukovyi Visnyk Natsionalnoho Hirnychoho Universytetu, 4, 134-140.

\section{About the authors:}

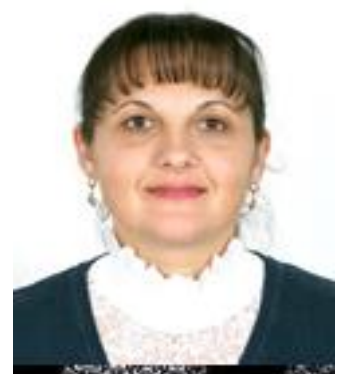

\section{Olena MAHOPETS}

$\mathrm{PhD}$, (Economics), associate professor, Central Ukrainian National Technical University, Kropyvnytskyi, Ukraine.

Research interests: the tax system, taxation, tax management

ORCID ID: https://orcid.org/0000-0002-2124-4026 


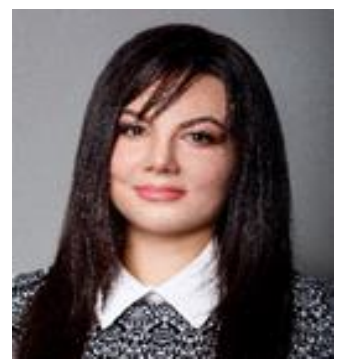

\section{Tetiana KORNEEVA}

Teaching assistant (Economics), Central Ukrainian National Technical University, Kropyvnytskyi, Ukraine.

Research interests: labour efficiency, labour productivity

ORCID ID: https://orcid.org/0000-0002-6434-0552

Copyright (C) 2020 by author(s) and ACCESS Publishing Press This work is licensed under the Creative Commons Attribution International License (CC BY) 